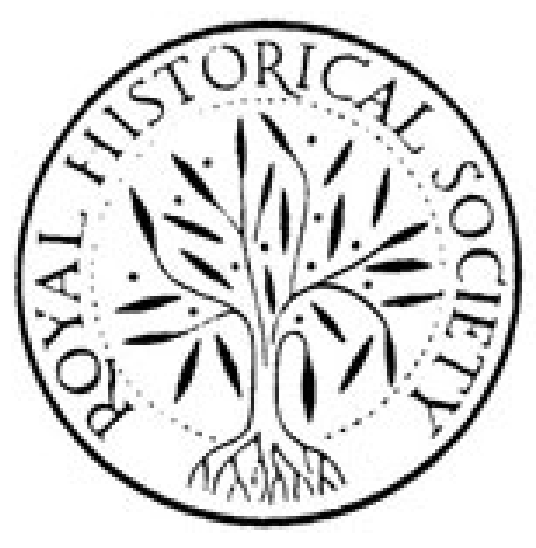

The Place of the Council in the Fifteenth Century: The Alexander Prize Essay, 1917 Author(s): Theodore F. T. Plucknett

Reviewed work(s):

Source: Transactions of the Royal Historical Society, Fourth Series, Vol. 1 (1918), pp. 157-189

Published by: Royal Historical Society

Stable URL: http://www.jstor.org/stable/3678352

Accessed: 14/11/2012 14:06

Your use of the JSTOR archive indicates your acceptance of the Terms \& Conditions of Use, available at http://www.jstor.org/page/info/about/policies/terms.jsp

JSTOR is a not-for-profit service that helps scholars, researchers, and students discover, use, and build upon a wide range of content in a trusted digital archive. We use information technology and tools to increase productivity and facilitate new forms of scholarship. For more information about JSTOR, please contact support@jstor.org.

Royal Historical Society is collaborating with JSTOR to digitize, preserve and extend access to Transactions of the Royal Historical Society. 


\section{THE PLACE OF THE COUNCIL IN THE FIFTEENTH CENTURY}

\section{The Alexander Prize Essay, 1917}

By THEODORE F. T. PLUCKNETT, M.A.

THE purpose of the following essay is to form some estimate of the place occupied by the King's Council in the political and administrative machinery of England during the eventful reigns of the Lancastrian and Yorkist Kings, while an attempt must also be made to discover the source of its power, to exhibit the means whereby it hoped to control the entire government, and to trace the fluctuations of its long conflict with the monarchy.

Indeed, the rule of Lancaster is remarkable for the abundant evidence it affords of the council's predominance; practically the first public utterance of the new dynasty was its founder's pledge to be governed by the counsel of the 'Sages and Ancients of the Realm,' ${ }^{\prime}$ and when, three-quarters of a century later, the line had ended in violence and exile, the last echo of its departed polity was heard in Fortescue's plea for more 'counsel'. Time after time, parliament prayed for 'sufficient counsel,' and as often did Henry IV inform them of the names of his advisers and swear them to be upright and true; later, in the troublous times of his grandson, it is still the council which was the storm centre, the council's dissensions which raged round the child-king's throne, and the council's collapse which eventually wrought his ruin. To appreciate how intimately the fortunes of the

${ }^{1}$ Rot. Parl. iii. 4I 5 (2). 
council were bound up with those of the nation itself, it is well to consider how widely its ramifications spread throughout the body politic; Parliament, Chancery, Exchequer, Law Courts-all these still remained so closely connected with the parent body, as represented by the group of men nearest the King, that it is difficult to determine at what period, and to what extent, one should regard them as separate institutions. ${ }^{1}$ This inter-penetration of the various government departments by the council can be regarded as the administrative aspect of the growing political supremacy of the crown. For centuries the crown was steadily gathering strength and building up a political unity out of the discordant elements of feudalism. One king was to be felt at work throughout the realm, and as the task grew heavier, it was one council which ensured the smooth working of the various organs of the administration. As a result, the fifteenth century possessed as highly centralised a constitution as one could expect to find, considering that communications-the nerves of a bureaucracy-were still so tardy ; such machinery as did exist, however, was to a striking degree amenable to council influences, and at times, subject to council control.

The paramount importance of the council is clearly witnessed, moreover, in Fortescue's famous treatise, which is substantially a commentary upon the institution's record under the Lancastrians. His considered judgment is of priceless value as evidence of the causes which wrought its fall, while his independence as a critic is assured by the fact that he has been claimed by Stubbs as the exponent of Lancastrian canons of policy, and by Plummer as a Yorkist-whence it may be safely concluded that he is expressing Lancastrian sentiment, freely modified in the light of subsequent experience. We shall have occasion to insist that the council's greatest

${ }^{1}$ See the detailed studies by Professor J. F. Baldwin in The King's Council (Oxford, Igr3), and cf. below, pp. r72-3. 
labour was to dispense the Royal favour and patronage, mainly among persons who, to modern minds, ought to have been paid a salary as civil and household servants, and that a prolonged conflict over the control of the various Royal seals was due to this factor. Fortescue is well aware of the importance of the matter, and unhesitatingly declares that all petitions asking for gifts or rewards should be discussed in the council, who were to consider the suppliant's merit from the standpoint of the King's purse. This done, our author thinks the rest, quiet, and contentment of the whole realm assured, for in such a council every difficulty could be removed before the King took action. Fortescue therefore thoroughly believes in council government, but nevertheless ruthlessly exposes all the abuses which ruined it under the Lancastrians, and attributes all the nation's woes to the reckless selfishness of the mighty princes, prelates, nobles, and officers of state, who used the King's resources to maintain their own trains of dependents, and met in the Royal council to transact their own, rather than the nation's business. So he sketches a model council of twelve laymen and twelve spiritual men-the wisest and best that can be found-who are to counsel continually. Tnese, it should be noted, contained not a single lord, but to them the King might add four nobles and four prelates. At their head was to be a Capitalis Consiliarius, but this dignity was reserved, not for a Bedford or a Gloucester, but for one of the simple twenty-four. Further, the simple men were to be paid a salary, but the noble men none-a daring break with contemporary practice, which consistently apportioned wages on the principle that 'to him that hath shall be given'. The Chancellor, Treasurer, Keeper of the Privy Seal, and the Chamberlains had long been the most assiduous members of the council, but Fortescue holds them all suspect; they may come to his ideal council if they like, he says, but he does not welcome them, and the appoint- 
ment of one of the twenty-four as chief councillor is a plain suggestion that the Chancellor-the honorary chairman-is not expected to be a frequent visitor. Fortescue is Lancastrian enough to call the lords at large Consiliarii Nati, but he will only have their presence when it is invited, and even the eight lords and prelates nominated by the King were to receive no salaries, and so they too could be trusted to stay away. The scheme was, of course, impossible; twenty-four men who had no great status (as things went in those days) but only good intentions, could not have carried on the government, while the greatest officials were alienated by intentional depression, and the whole baronage slighted. The project hoped to avoid the social difficulties which lay at the root of the trouble by simply ignoring them. Nevertheless, the suggestion is of immense value, not as political science, but as evidence of the case it meant to cure, and no plainer statement could be desired of the council's place in the constitution and of the fatal results of the baronial exploitation of its powers. ${ }^{1}$ Then we must also note what Fortescue has to tell us about the great council (which will be more fully described later ${ }^{2}$ ), if only because there is a prevalent opinion that he does not mention such a thing. ${ }^{3}$ Distrust and caution are the most he expresses. He frankly concedes the argument drawn from history and admits that the

${ }^{1}$ In one point of detail we clearly see the lawyer, for he recommends keeping a ledger ' as a registir or a ordinarye howe thai shall doo in euery thynge,' which suggests a precedent-book rather than a journal. As a matter of speculation one might note some curious leaves of parchment which are scattered through the MS. Cotton., Titus E. v., among comparativeiy modern transcripts on paper of rolls of parliament. The leaves in question consist of fair copies in contemporary handwriting of various ordinances for council procedure such as we shall notice later, and seem to have originally formed a book which was subsequently dissected, and bound up with the later and somewhat larger volume. Was this such a book as Fortescue mentions ?

${ }^{2}$ See below, pp. I65-70.

${ }^{3} \mathrm{It}$ is a curious lapse of his editor to say (pp. 4, 307) that Fortescue makes no reference to great councils, seeing that a whole Chapter (XVI) is devoted to the subject. 
' Romaynes prospered whiles thai hade a Grete Counsell ; ... be wich ensample it is thought bat yff the Kyng have such a Counsell as is beffore specified [i.e. a 'great Council' like the Senate], his lande shall not only be ryche and welthy, as were be Romans, but also is hyghnes shalbe myghty, and off poiar to subdue his ennemyes, and all oper that he shall liste to reygne uppon'. This phrase is widely different from the usual confidence with which he states his opinions, and he surely means us to accept the impersonal 'it is thought' as dissociating him from the view that follows.

Fortescue's suggestion of a council of simple men clearly shows that he places the blame for the catastrophe of the fifteenth century upon the inordinate degree of influence possessed by the magnates, while his faint praise of the great council-their own peculiar organmust clearly bear the same interpretation.

It is considerations such as these, therefore, which suggest an examination of the council's place in the constitution under the Lancastrian kings. Many possible lines of research present themselves, and several of them have been pursued with most important results ${ }^{1}$ and therefore need not be discussed in this essay which is more particularly concerned with a few points only which have received so far little or no attention. Thus it will in the first place summarise the results of research upon the history of the great council, ${ }^{2}$ with a view to showing from the records its general agreement with the continual council in a common tendency towards oligarchic rather than monarchic ideals, tracing further the constitutional means whereby this close co-operation was made possible, ${ }^{3}$ and the political theory which sanctioned it. ${ }^{4}$ Then also must be discussed the administrative machinery through which they exercised

'See Baldwin, The King's Council; Palgrave, Original Authority, etc.

2 Below, pp. r65-r7r.

3 Ibid., pp. I72-3.

TRANS. 4 TH S. - VOL. I.

${ }^{3}$ Ibid., pp. I74-5. 
their powers, and reasons must be submitted for the opinion that the procedure connected with the Great Seal, the Privy Seal, and the Signet is of great significance in this respect, and that these seals were the subject of an important constitutional struggle, which has hitherto passed unnoticed. ${ }^{1}$ In conclusion, something must be said of the very obscure period of the Yorkist and early Tudor reigns, and the suggestion will be made that these critical years saw, not so much the fall of the council, as a striking change in its functions, and consequently in its political position. ${ }^{2}$

Before proceeding to the examination of these problems, however, some remarks on the nature and extent of the original materials available may be of service, not only as a bibliography of sources, but also by reason of the fact that the distribution of council documents is a valuable indication of the council's position in the nation's economy. In the first place it must be noticed that there is no officially compiled corpus of council acts-be it in the form of minutes, registers, rolls, or decree booksdating from our period. ${ }^{3}$ Consequently, the records of its work must be sought among the general collections of archives, where they may be traced scattered through a number of different departments. This statement of fact may very properly be regarded as significant of the council's constitutional position; it was not one of a number of independent organs of state, so much as a rather indefinite body at the centre from which the other departments radiated, and from which they received constant inspiration and control.

For example, the Patent and Close Rolls of Chancery consist of entries of acts which have reached the last of

1 Below, pp. 176-183.

${ }^{2}$ Ibid., pp. 185-9.

3 There are a few exceptions to this general statement which nsed not be discussed here, but in no case have we an undoubtedly official roll or register, while on the other hand, it is certain that the compilations in question are only selections which are far from exhaustive. 
a long series of stages, but the rolls do not always clearly indicate what those stages were, so that unless the text of the patent or writ expressly refers to them, we have to rely entirely upon the docquet at the end of the record. When this is 'Per Consilium' or 'Per Regem in Consilio' there can be little hesitation in regarding the entry in question as an authentic council act; on the other hand, of course, 'Per ipsum Regem' clearly tells the opposite tale.

In the fifteenth century, however, matters are not often so simple as this, and the usual docquet 'Per breve de Privato Sigillo,' is as much as we can learn in most cases from the roll. It may have been the King who set the privy seal in motion at his own will, or it may have been that the council procured the privy seal upon their own authority. To distinguish these two cases is of great importance to our subject, but the docquet on the Chancery Rolls is the same for both, and therefore gives no guidance in the matter. ${ }^{1}$ It thus becomes necessary to seek the methods by which the privy seal was procured, in the hope that here we shall be able to make a fair estimate of the relative influences of the King and his council. Now the authority upon which the privy seal was applied was carefully preserved by the privy-seal office as their warrant, and it is upon this collection of documents that our judgment of the council must rest. They present a considerable variety

1 For example, the constableship of Shrewsbury Castle was conferred on Bewes Hampton by patent in 1436 (Cal. Pat. Hen. VI. iii. 25), while Thomas Chace was reinstated as Chancellor of Ireland by a similar instrument (ibid. 28). In both cases the patent was procured 'By writ of Privy Seal,' but the difference between the origins of these grants can be seen in the respective warrants which moved the Privy Seal; the former was a petition endorsed in a boyish hand 'R.H. nous auons graunte'; the latter bears no hint of the King's intervention, being expedited by a council consisting of the Duke of Gloucester, the Archbishop of York, the Bishop of Norwich, the Earls of Warwick, Stafford, and Northumberland, Lords Scrope, Hungerford, and Tiptoft, the Chancellor, Treasurer, and Keeper of the Privy Seal (P.R.O. Council and Privy Seal, file 58 , I Nov., 5 Nov.). 
of forms, the most frequent being that of the petition, which having been marked in some way-by endorsement or signature-to indicate the granting of the request by the King or council, or sometimes both, was sent straight to the office of the privy seal there to serve as warrant for the issue of the seal. Other frequent forms are drafts of documents which, having been considered by the council, were kept as reference copies of the privy seal's out-letters, while in lesser numbers are to be found minutes and agenda. In every case, however, the document was primarily intended as a warrant authorising the use of the privy seal, and hence they were accumulated as a matter of routine in its office, which periodically transferred its contents to the Treasury. In the Public Record Office they are therefore classified as 'Exchequer: Treasury of Receipt, Council and Privy Seal,' and are now mounted chronologically in ninety-five files. Neither list, index, nor calendar exists, beyond a mere note of the dates comprised in each file. The collection in its present state is very irregularly preserved and grave losses must be presumed. As it is, a large proportion are damaged and only partly legible.

A number of these documents were abstracted from official custody, it seems, in the early seventeenth century by Sir Robert Cotton, and incorporated into his library, chiefly in the manuscripts Cleopatra, F. iii., iv., and v., which were printed, with additions from other sources, by Sir N. H. Nicolas, as Proceedings and Ordinances of the Privy Council. Most of the types of council document may be found represented in these volumes, but by no means in the same proportions as existed in the council's own day, for a comparison of Nicolas' volumes with the Record Office files shows that Cotton had picked out nearly all the minutes and agenda, together with the longest of several rolls, neglecting, however, most of the more detailed proceedings which were recorded only as endorsements on petitions. The selection thus consists. 
mainly of pieces of general political interest, relating to famous men and dramatic incidents, and revealing the council chiefly in its deliberative aspect. The Record Office sources correct this view by impressing one with the vast amount of purely administrative work performed by the council. Here it was, in fact, that the crown and council quarrelled, and it is in the Record Office files that the rise and fall of the council's fortunes must be traced.

These documents, however, have not yet become generally known, although Professor Baldwin's work, which is the only considerable example of their use, has clearly shown that much new light upon the council may be expected from this source.

Using this new evidence, therefore, as the main basis of research upon the great council, ${ }^{1}$ it may be noticed that during sixty years of Lancastrian rule, the great council met between forty and fifty times, although there were only twenty-two parliaments in the same period. The surest way of forming a judgment, of course, is to examine, one by one, all its known acts, and then there can be no doubt of the verdict, while by taking only some of the most important ones we shall clearly see their general nature.

Henry IV was kept in perpetual subjection by almost annual meetings of the magnates. At the very beginning of the reign, the lords in parliament exacted the famous pledge already cited, ${ }^{2}$ and within three months they enforced it, for rebellion and widespread dissatisfaction had raised problems which the continual council was at first afraid to face, and so it reserved a long schedule of difficulties for the lords to settle in a great council. What to do with King Richard, how to treat the men

${ }^{1}$ For a detailed study upon which the following remarks are based, see The Great Council in the Fifteenth Century (thesis by the present writer in the University Library, South Kensington).

${ }^{2}$ Above, p. $\mathbf{5 7}$. 
who lynched Kent, Salisbury, Huntingdon, and Despenser, how to keep some degree of security for life and property, where to get money, how to wage war against France-in fact, all the government's outstanding questions were thought proper for the magnates to settle. ${ }^{1}$ When they met, ${ }^{2}$ they conducted some diplomatic negotiations with France, and finally prepared for war by raising money and men among themselves, and authorised the King to ask various abbots, who had not been present, to make loans, which several did, ${ }^{3}$ thus sparing the commons from taxation. ${ }^{4}$

In March I 40 I a great council made some ordinances for Wales ${ }^{5}$ in January 1402 one took the place of a parliament, ${ }^{6}$ ordered an inquiry into the Royal finance, ${ }^{7}$ and did some judicial work $;^{8}$ in August ${ }^{4} 404$ the Welsh war was discussed at Lichfield, ${ }^{9}$ while in 1405 the Duke of York was arrested after a dramatic scene in the great council which also flatly refused the King's demand for money, ${ }^{10}$ and after a long adjournment, broke up in absolute deadlock; ${ }^{11}$ in 1406 it called all the customers. and controllers in England before it ${ }^{12}$ - such is the barest epitome of what some of Henry IV's great councils did,

1 Nicolas, i. Io7-Ir. When the continual council had got over its panic, it. withdrew some of these articles, and took independent action upon them.

2 Ibid. 102-6; Rymer, viii. 125-7.

${ }^{3}$ Council and Privy Seal, file 26, contains some of their replies. Cf. Ann, Hen. 332.

${ }^{4}$ Adam of Usk, 44 ; the Editor's theory that Nicolas, i. 107-II, does not refer to a great council is disproved by the fact that the heading appears on both sides of the manuscript; thus it could not be accidental as he suggests. Adam of Usk, 20I-2, n. See MS. Cleopatra, F. iii., ff. $g$ and $g b$.

${ }^{5}$ Rymer, viii. I84-5.

${ }^{6}$ Council and Privy Seal, file II (Jan. I4); MS. Add. 24062, f. I36.

${ }^{7}$ Nicolas, i. r8o.

${ }^{8}$ Chanc. Warrts. i. I540 (Hilary and July I8).

${ }^{9}$ Nicolas, i. 233-5; Cal. Pat. Hen. IV, iii. $4^{\mathrm{r} 2}$; Chanc. Warrts. i. I54 I (Aug. 28-9). 29).

${ }_{10}$ Rymer, viii. 386; Ann. Hen. 398-9; Council and Privy Seal, file I7 (Jan.

11 Wals, ii. 268.

${ }^{12}$ Issue Roll, Pasch. 7 Hen, IV (June 7). 
and it unmistakably shows that they held very high views of their place in the government.

The next reign also bears striking witness to the commanding position held by the great council, for Henry $\mathrm{V}$ himself found it prudent to exercise some caution in his dealings with it over the reopening of the war with France. These negotiations have not yet been entirely unravelled, but it seems clear that France had no desire for war, and that the English magnates and commons showed so little enthusiasm for the project, that Henry had some trouble in carrying his point, for it must be confessed, it was Henry himself who must bear the blame. The two nations were slowly exchanging peaceful embassies, which cautiously progressed in their discussions from short truces to a general truce, and even broached a treaty and a marriage alliance, ${ }^{1}$ when Henry caused universal consternation by commissioning an embassy on May 3I, I4I4, to conclude a treaty, negotiate a marriage, and demand his 'rights'. Four days later he opened other negotiations for a marriage treaty with Burgundy. ${ }^{2}$ Charles was in dismay, for Henry had shown his hand, and those who knew the facts could have had no illusions, but when a great council met, on September 22 following, ${ }^{3}$ these events were still hidden from it by the closest secrecy, and the prelates, lords, and knights who assembled at Westminster were totally ignorant of the fact that Henry had made a formal demand for his 'inheritance' nearly four months before. The King, however, assumed an air of indecision, and asked them 'of their goodness and of their good counsel to show him as touching the right and title that he had to Normandy, Gascony, and Guienne '. ${ }^{4}$ A discussion seems to have followed, resulting in a very cautious reply. The lords apparently did not risk an answer, but the knights, upon their own and the lords' behalf, re-

\footnotetext{
${ }^{1}$ Rymer, ix. 5I-5, 60, 69-7r, 9r-103.

2 Ibid. $13 \mathrm{r}-3, \mathrm{I} 36-7$.

${ }^{3}$ Issue Roll, Pasch. 2 Henry V, m. 5 .

${ }^{4}$ Brut, ii. 374 (cf. 552).
} 
hearsed the King's request for their advice, and expressed their conviction that so Christian a prince would not begin a matter displeasing to God, but eschew the effusion of Christian blood, and not make a war out of mere wilfulness; therefore, they unanimously asked the King to send an embassy, and if an offer by the King to moderate his claims produced no settlement, then they were prepared to do their duty. ${ }^{1}$ This reply doubtless confirmed Henry s anticipation of reluctance, if not actual opposition in the great council, and increased his caution. In November a parliament met, and made the same request for more negotiations, ${ }^{2}$ so the King, had to conciliate the magnates and commons by commissioning a fresh embassy; so little likelihood did there seem of war that the Commons in Parliament were discussing the position of alien priories in England, 'in case a final peace with France should be made'. ${ }^{3}$ The diplomatists were still negotiating when Henry declared his determination to make war before the City fathers. ${ }^{4}$ Once more the great council met, and on April I6, 1415, the question of war was again raised; the failure of the negotiations was set forth, in spite of proffered concessions (as the King said), and at last the King obtained the grant of an aid. ${ }^{5}$

The fact that a King of Henry V's disposition should find it politic to treat his great council with such caution, is faithful testimony to its strong position, while their unanimous demand for negotiations and their appeal to his sense of justice, show that they were able, if they had the inclination, to give him a very independent opinion upon matters referred to them. Needless to say, once the war began, we hear no more of great councils under Henry V, and it is not until the accession of his son that they resume their functions.

The next reign provides the clearest statements we

\footnotetext{
${ }^{1}$ Nicolas, ii. 140-2. $\quad{ }^{2}$ Ibid. 150.

${ }^{4}$ Riley, Memorials of London, 604.

${ }^{3}$ Rot. Parl. iv. 22 a.

${ }^{5}$ Nicolas, ii. I50-I, I55-8.
} 
possess of baronial political thought as it affects the great council, and the surest examples of its working in practice. A continuous decline in its power and prestige still went on in spite of the occurrence of a long minority, and the subsequent victory of Henry VI over the continual council might have been repeated over the great council if it had not been for the intrusion of the dynastic question.

At the beginning of the reign, the lords at large assumed control of the government and the seals, and parliament subsequently ratified their action, ${ }^{1}$ while the immense task of renewing and confirming legal documents that had lapsed on the demise of the crown was committed entirely to the great council. ${ }^{2}$ Perhaps this dreary work gave the lords so bad an opinion of administration that they lost their taste for it; certainly, they made no considerable attempt to restore the conditions of Henry IV's reign, and when great councils do meet, we find the personal element steadily overshadowing the national interest. In ${ }^{4} 27$ they sanctioned Gloucester's adventure in Hainault $;^{3}$ in 1429 they were convened to arrange for the coronation and face an annual deficit of 30,000 marks, but all other business was cast into the shade by Gloucester's dramatic attack on the Cardinal of England, ${ }^{4}$ while two years later they granted Humphrey an enormous salary. ${ }^{5}$ In I 434 Gloucester attacked Bedford before the great council. ${ }^{6}$ Not until October 1436 do we find one which did much administrative and judicial business such as we found under Henry IV, and then it certainly did work well-a blunder by the Exchequer clerks was rectified, some shipping regulations were made, a widow's long complaint of violence and oppression was answered, a little war-finance transacted, and an Archbishop released from a legal tangle ${ }^{6}$

\footnotetext{
${ }^{1}$ Rot. Parl. iv. 172 b.

2 Ibid.

${ }^{3}$ Nicolas, iii. 27r-3.

${ }^{4}$ Ibid. 322-6. $\quad{ }^{5}$ Devon, Issues, $4{ }^{\mathrm{I}} 4$.

${ }^{6}$ Nicolas, iv. 2ro-r6.

${ }^{6}$ Council and Privy Seal, file 58 (Oct. 2 I-30).
} 
-all this shows the best aspect of the great council's functions, but for the last time; many more assemblies followed but do not appear to have done much, so that one is tempted to lay stress upon the facts that in 1437 Henry had begun to free the seals from council control, ${ }^{1}$ and in 1436 met the last great council which did much actual governmental work, and to claim that they are more than mere coincidence. In any case practically nothing is heard of great councils until in 1453 the King's malady revived the conditions of the minority. Henceforth great councils are called, but with different motives. There had been intrigues and quarrels in the continual council for the last twenty years; now it was almost private warfare among the magnates of the great council, so that time after time they were convened in the hope of making peace, ${ }^{2}$ at home, if not abroad, but the lords would not attend. ${ }^{3}$ There were no spoils to distribute, for as we shall show later, the King had recovered control of the seals, and as he could not offer exorbitant wages to all the lords of the land, they simply stayed away. Occasionally they met, as when there was a chance of meddling in the King's household, ${ }^{4}$ but national work was treated with complete apathy. ${ }^{5}$

The Wars of the Roses began, but still the King tried to make a reconciliation at the great council of $1458,{ }^{6}$ when his personal influence led to the great procession to St. Paul's, but it was only in his own presence that his obvious zeal and earnestness dominated those around him. It may have been his consciousness of this that led him to keep as many lords at court as he could, thus making his continual council almost as big as the great council; but all his efforts only slightly deferred the in-

${ }^{1}$ See below, p. r8r.

2 Nicolas, vi. r63-4.

${ }^{3}$ Ibid. 2r6-7; Council and Privy Seal, file 85 (m. i.).

${ }^{4}$ Ibid. 220-33.

5 'The lordes Chaunceller, Tresorier, and therle of Sar' [are] in London, and noo more lordes at the begynyng this diy of the grete counsail. Many men say that there shuld be, but thei wote not what.'-Paston Letters, i. 392.

${ }^{6}$ Whethamstede, i. $296-308$. 
evitable catastrophe, which included both the King and the council. If the magnates could not rule the State, they could ruin it.

That the baronial theory was extreme can be seen from one or two sentences in which they express their views on politics. Thus they claimed that during the minority of the King, at least, the government of the realm pertained to 'the lords spiritual and temporal as they be assembled in parliament or great council, or else, them not being so assembled, unto the lords chosen and named to be of his continual council '. Even in more normal times they averred that the King's progenitors had a laudable custom of settling their finance every year in great councils. ${ }^{2}$ That they played a prominent part in national affairs under Henry IV has already been shown, while their gradual declension from this position as they became more absorbed in the personal and family politics of the time has also been noticed. When all this is read in connection with Fortescue's remarks on the continual council, it is evident that both bodies pursued the same ends, that is to say, both tried to appropriate as much of the Royal power as they could, and to reduce the King to the position of a fainéant. The great council was to control broad questions of policy, while the continual council was to determine the minor matters of administration.

It is not sufficient, however, merely to say that both bodies contained the same class of magnates, and that both pursued a similar policy, for they had much more in common than this. There was, in fact, some obscure bond which united the two in a most remarkable manner, not only with each other, but also with parliament, and it now remains to discover the constitutional basis of the singular unity which pervaded the three institutions.

'Nicolas, iii. 233.

${ }^{2}$ Ibid. v. $64-5$; there is no trace of these annual great councils. 
A few examples will show the peculiar difficulties of the subject. Beginning with the great council and parliament, we find that their relations were most intimate ; there was a 'great council in parliament' with an implied contrast with a great council out of parliament. ${ }^{1}$ In one of Henry IV's early parliaments 'the necessity of the realm was shown to the barons and commons of the realm by my lords of the great council.' ${ }^{2}$ A letter of Inspeximus 'by the advice of the Great Council ' was procured 'by the King in Parliament'. ${ }^{3}$ Business begun in parliament might be finished after its dispersal in the great council, ${ }^{4}$ and even while parliament was actually in session we find the great council at work, ${ }^{5}$ and in several instances a great council was held as a preliminary to Parliament. ${ }^{6}$ Then also, the continual council was very closely connected both with parliament and with the great council. The phrase 'Council in parliament ' constantly occurs ${ }^{7}$ and examples illustrating its meaning are not hard to find; agenda for parliament occur among the council's papers $;^{8}$ and proposed legislation was at times drafted by the council, ${ }^{9}$ which was, in fact, the executive board of parliament, as may be seen

${ }^{1}$ Cal. Pat. Hen. VI, ii. 297 ; Nicolas, iv. 185-6, 219, 287-8; Rot. Parl. v. $43^{8} \mathrm{~b}$.

2 Nicolas, ii. 58.

3 Cal. Pat. Hen. VI, iii. 128.

4 Rot. Parl. iii. 457 (r6) is the petition; March ro was the last day of the parliament (ibid. 465 , No. 44 ), and the ordinance by the advice of the great council was made March 18 , and ratified on 2and (Rymer, viii. 184-5). Cf. Rot. Parl. iii. 576 (40), and the great council's inquiry, July 8, Issue Roll, Pasch. 7 H. IV, June 7, cited above, p. I66, n. I2.

${ }^{5}$ Rymer, viii. 504-7, and the parliament of October-December, r407, Cal. Pat. Hen. VI, i. 9-23, 32-3, etc., and Hen. VI's first parliament. Cf. ibid. v. 215, and Parry, Parliaments and Councils, 184 , for another instance in $\mathrm{I}_{449}$.

${ }^{6}$ Report on the Dignity of a Peer, iv. $869 \mathrm{ff} . ;$ Nicolas, iv. 67. Cf. what was regarded as a model writ by Occleve, MS. Add. 24062 , f. 5 .

${ }^{7}$ Nicolas, i. 18 ; iv. 4 ; vi. 345 ; Cal. Pat. Hen. IV, i. 369 ; iii. 153 ; Rot. Parl. iii. $5^{2}(9), 54\left(\mathrm{r}_{4}\right)$. This and the three preceding notes could be considerably extended by other instances.

${ }^{8}$ Nicolas, i. $283-7$, etc. $23 / 7$.

${ }^{9}$ E.g. a bill to incorporate Plymouth; Chanc. Council and Parliament, file 
from a number of petitions which bear endorsements such as this:-

'Concessum per Parliamentum apud Leycestriam.

$$
\begin{array}{lll}
\text { Johan } & \text { J. Ebor. Canc. } & \text { P. Elien. } \\
\text { T. Dunelm. } & \text { Typtot. } & \text { J. Bathon. }
\end{array}
$$

Cromwell." 1

Precisely the same relationship existed between the council and the great council. ${ }^{2}$ Probably in most cases the great council was called on the advice of the continual council, ${ }^{3}$ which also prepared its agenda, ${ }^{4}$ and at times, we may suspect, helped it to a decision, ${ }^{5}$ besides authenticating its acts in the manner just described.

These are only some out of many instances, which all indicate a considerable amount of inter-penetration by all three bodies. Moreover, in point of actual composition, the great council and continual council at times seem identical, but still we cannot say that they are the same, even in such circumstances, for the two bodies are referred to by contemporaries as being quite distinct. To describe the constitutional place of several institutions, each of which exhibits every sign of self-consciousness, regarding the others as quite external to itself, and pursuing a policy of its own, and yet which are at the same time inextricably entangled in all directions, is no easy matter, when one has to use modern words with their clearly defined associations.

It must have been a very different state of mind from that of the modern age which could create and use such

${ }^{1}$ Council and Privy Seal, file 47 (July 27, 1426 ). Several others are in Chancery, Warrants, Series i., files r540-48. Cf. Nicolas, iv. 76.

${ }^{2}$ Cf. Nicolas, iii. 95-6 (original in Council and Privy Seal, file 4r, May r9); MS. Add. 4603, ff. 208-9 b.

${ }^{3}$ Nicolas, i. 179 , and other instances.

${ }^{4}$ Ibid. ro7-rr, etc.

5 The large grant to Gloucester was perhaps settled on November 28, in a full meeting of the continual council (Nicolas, iv. 104), though the result was formally announced in the great council on the 29th (ibid. ro5). Cf. Devon, Issues, 4I4. 
machinery, and it is only in reconstructing the political ideas of the time that we can hope to find the spirit which worked within so strange a frame. By 'political ideas,' moreover, we must understand not so much the formal theories of the schools, as those vague, hazy notions of the clerk in the office and the baron at court, which, in the Middle Ages, probably had more direct influence on the moulding of the constitution than had the learning of the philosophers. By the nature of things, it is only very rarely that we get a hint of what is working in the minds of public men whose labours ceased over four hundred years ago, but when we do, the result cannot but be of fascinating interest. A case in point is the rancorous manifesto $^{1}$ issued by the Duke of Gloucester in I440 against his inveterate foe, Cardinal Beaufort. When Henry $V$ let Beaufort accept the cardinalate, said Gloucester, it was only with the intention of keeping him in Rome as English agent, 'and not to abide in this lande as eny part of youre counsaille, as be alle other lords spirituell and temporell at the parlements and greet counsailles, whan youre liste is to calle hem'. In this phrase Gloucester enunciates an idea which must have been unexpressed in the minds of many of his contemporaries. All lords spiritual and temporal, we are told, whether in parliament or great council, are nevertheless still part of the'King's 'counsaille'. Similarly, another phrase mentions the 'Grantz du Parliament et autres du Conseil du Roy'.2 This is surely evidence of a hazy element of 'counsel' which is wide enough to include parliament and great council, as well as the continual council, and unite them all in the common relationship of counsellers of the King. In this principle is a basis for that unity which has been so strongly felt in studying mediæval institutions. We cannot call it a unity of form, saying on the strength of statistics of at-

${ }^{1}$ Stevenson, Letters and Papers of Henry VI, rI, ii. 442.

2 Ancient Petitions, $\mathrm{rO}_{4} 6_{4}$; cited by Baldwin, The King's Council, 243. 
tendances that there is only one king's council, and denying the separate existence of the great council, but we can safely call it a unity of spirit, insomuch as continual council, great council, parliament, and a number of lesser bodies all owe 'counsel' to the King. ${ }^{1}$

The government lay in the hands of a circle of clerks, courtiers, and nobles who formed a body of a very indistinct and nebulous nature; several points of greater brightness and clearer definition can certainly be discerned within it, but we must remember that they are set in the midst of a tenuous medium which binds them together to a degree altogether indeterminate, and that these nuclei themselves are amorphous in the extreme, fading imperceptibly away into the surrounding haze. So, out of the elastic group who owed 'counsel' to the King, some would draw closer together for a time, and having fulfilled their purpose, disperse. Practically the same men may meet with a different intention on another occasion, giving one the impression of a different institution, and then they, too, are resolved into the mysterious 'counsaille'. Thus we may find the rarefied council condensing at various times into the 'continual council,' the 'great council,' the 'council of the parliament,' ${ }^{2}$ the 'parliament of the council,' ${ }^{3}$ and so on. In certain cases the frequent repetition of similar processes has given us fairly well-defined institutions, as the continual council, the great council, and the parliament, but in the fifteenth century all three retain enough anomalies to remind us that they are still influenced by their earlier history, and still 'part' of the much wider 'counsaille'.

${ }^{I}$ As a rule, in fifteenth-century MSS. consilium serves for all purposes. The earliest instances of the use of concilium I have noticed are from the pen of Thomas Kent, who was clerk of the council for some years; they are to be found in Council and Privy Seal, file 72 (Feb. $\mathrm{I}_{3}$ and 27, $\mathrm{r}_{444}$ ). In the first of these it seems that consilii has been altered to concilii.

${ }^{2}$ Nicolas, iv. roo. 264 .

3 'Convocavit regni proceres ad Consilii Parliamentum,' Walsingham, ii. 
The general character of the continual council has now been shown from Fortescue's tract, while the influence of the little-studied great council has also been briefly traced from such of its acts as can be found. Then, too, their close intimacy has been exhibited and ascribed to the notion that the King could command 'counsaille' from a very wide circle of men, and that all organised councils were equally parts of this indefinite class of counsellors. The general proposition of the council's vast power is established, but the source of that power has not been fully examined. It is here suggested that the main basis of the council's strength is to be found in the mass of technicalities governing seal-procedure. The immense significance of the seals in constitutional history can hardly be realised as yet, until the field has been systematically explored; much more than a mere picturesque prototype of 'red tape,' they were the very pivots upon which the wheels of state revolved, and it may be suspected that they were the subject of more than one constitutional struggle of which the books say nothing. A sure index of their importance is afforded by the rapid rise of their holders to positions of the first rank in the state. The clerk who held the King's seal became the later Chancellor, enjoying by his office unrivalled power and wealth. Similarly the 'Clerk of the Privy Seal,' by the beginning of the fifteenth century is called the 'Keeper of the Privy Seal,' and well before the century is out he is 'My Lord Privy Seal, ${ }^{1}$ drawing a handsome salary of $£ 365$ per annum. ${ }^{2}$ Then there was the Secretary, who, though rather obscure at this period, eventually wielded the King's Signet to such good purpose that he became a Secretary of State. To hold a Royal Seal evidently meant vast possibilities in political development. As a result of their

${ }^{1}$ Nicolas, Proceedings and Ordinances of the Privy Council, v. 28, 29, 40, where the title is applied to William Lyndwoode. The regular use of the style became settled under the Tudors.

${ }^{2}$ Cal. Pat. Hen. VI, vi. 65. 
increasing importance, each of these dignitaries in turn followed the usual tendency of bureaucrats, by trying to arrange that as much of his office's work as possible could be carried on by subordinates without his constant personal intervention, he himself being left free for more responsible affairs. Of the Chancellor's many functions, that of preparing and sealing acts of state was most easily adapted to this end, and so the routine of the Chancery began to expect a written warrant which would justify its issue of the great seal as a matter of course, thus removing the responsibility for the act from the Chancellor, and placing it upon the official who drew up the warrant. This, of course, was the Keeper of the Privy Seal, and by the beginning of the fifteenth century the privy seal was the most usual approach to the great seal. This alone would have virtually transferred to the privy seal a considerable amount of the power exercised by the older instrument, but there was another contributory source almost as great, derived from an ordinance made in 1338 , which forbids the payment of any sum from the public funds by Exchequer officials, without a sufficient writ under the privy seal, or in cases of emergency, a warrant signed by the councillors, which was to be subsequently ratified by privy seal. ${ }^{1}$ By the opening of our period, therefore, both the application of the great seal, and the issue of money from the Exchequer, were controlled to a considerable extent by the privy seal. As may be expected the Keeper's importance rapidly increased; he was the most constant attendant at the council, which now frequently entrusted him with delegated authority, ${ }^{2}$ while clerks from his establishment were assigned to do what clerical work the council required-and he, too, desired to organise

${ }^{1}$ Rymer (Record Edn.), II, ii. Io49-50.

${ }^{2}$ Examples are in Nicolas, i. $I_{4}$ d, 76 ; iii. r93. In $\mathrm{I}_{424}$, owing to his prolonged absence on other business, the Keeper executed a general warrant for the acts of Robert Fry, who was to hold the seal in his stead. Public Record Office, Exch., T.R., Council and Privy Seal, file 44 (Feb. 28).

TRANS. 4TH S. - VOL. I. 
his office, and to substitute routine for personal supervision, by requiring, like the Chancery, some warrant before affixing the privy seal. Whoever could become the recognised means of moving the privy seal, could also thereby direct its authoritative commands to the Chancery, and through the Chancery, could dispense the immense Royal patronage, lay and ecclesiastical, which was one of the chief perquisites of office. It was in fact this which lay at the root of the whole matter; Fortescue tells us how hosts of offices were regarded as the natural rewards to be distributed among those who had influential friends to procure them, and it was over this division of the spoils that the crown and council so often disagreed. As far back as the middle of the thirteenth century, the council had formally claimed to control the great seal, ${ }^{1}$ and it was exactly the same issue involved in the question as to how the privy seal was to be procured. The council claimed that nothing should pass the great seal unless it had already passed the privy seal, and that nothing should pass the privy seal except what the council chose. The crown, on the other hand, attempted to procure the great seal directly by the signets (over which the council had no effective control) and, as the Chancery's extreme reluctance made this difficult, to force the privy seal to accept without question the signet or the sign-manual as a sufficient warrant. The varying fortunes of the conflict can be discerned, with some difficulty, in the long series of ordinances governing council procedure which are to be found at various dates among the Proceedings of the Privy Council and on the Rolls of Parliament.

The circumstances of Henry IV's accession undoubtedly placed him at a disadvantage at the outset, and the Council accordingly took an independent attitude; of the warrants preserved by the privy seal office, it seems that almost all were executed by the Council,

1 Provisions of Oxford, Del Chanceler. 
a clerk having endorsed them with a statement of its assent and a list of those present. But although the council's right to move the Privy Seal was so well established, the King still exercised a concurrent power by ordering the Chamberlain to sign documents, adding Le Roy lad graunte, or words to that effect, and possibly also used the signet-which was still a private rather than a public instrument-instead of the privy seal for giving executive orders to various officials. What was said about the matter at the time we shall probably never know, but it is certain that the King had to sustain a heavy defeat with as much grace as he could, for in May 1406 he had to concede that all bills endorsed by the Chamberlain or Under-Chamberlain, all documents under the signet, and all orders to the Chancellor, Treasurer, Keeper of the Privy Seal, and all other officials, whether under the signet or not, should henceforth be made only by the advice of the council. ${ }^{1}$ The council had taken up a position which contemporary opinion itself might have regarded as extreme, while it may be doubted whether the council had adequate means of controlling the King's actions to the extent contemplated by the ordinances. Be this as it may, it is quite clear that bills signed by the Chamberlain are numerous at this date, although the council's concurrent powers are also well-attested in the files. The rest of Henry IV's reign is devoid of incident, and apparently the King's broken health rendered him unwilling to renew the struggle for powers he was too infirm to wield.

Henry V seems to have sought release in war from an over-officious civil service, and his reign shows no trace of the renewal of the controversy. It is most likely that his pre-occupations in France afforded the council a fairly free hand at home, but on his unexpected death the whole situation suddenly changed. The new King was only an infant, and the council beheld a tempting

${ }^{1}$ Rot. Parl. iii. 572-3. 
prospect of future power. The Duke of Gloucester, as Protector, certainly made some attempt to take up the crown's cause against the council, and even succeeded for a time in making his signet procure the privy seal, ${ }^{1}$ while it may be also due to his insistance that it was ordained in parliament that the clerk should write on each document the names of those who passed it, ${ }^{2}$ which thus helped to impress upon the individual councillors some sense of their responsibility; nevertheless, the Council claimed and obtained the disposal of the more important offices and all the feudal casualties, ${ }^{3}$ and was unquestionably the dominant factor in the situation. In I 424 it was further ordained that Gloucester was not to grant offices, and that all who assented to a 'bill' should sign it with their own hands, ${ }^{4}$ and hundreds of autographs of Bedford, Gloucester, Beaufort and the rest testify that this rule, originating perhaps with Gloucester, was faithfully observed. After this, no important change upon the subject was made during the King's minority, the foregoing regulations merely being repeated several times. ${ }^{5}$

The Council was now enjoying the power it had won, and the frequent denouncements of corruption, abuse of official privilege, perversion of justice, harbouring of criminals, and maintaining of quarrels by councillors, give reason to suspect how unworthily they discharged their trust.

Amid such rampant malversation, it is impossible to believe that Bedford was indifferent; his prolonged absences in France, however, prevented him from forming a continuous policy, and the most he was able to do

1 Nicolas, iii. I5.

2 This is a reversion to the Council's practice under Henry IV, which, however, was modified under his successor, the list of names being generally omitted from the endorsement.

${ }^{3}$ Rot. Parl. iv. I76 (29); Nicolas, iii. I7-I8.

${ }^{4}$ Rot. Parl. iv. $20 \mathrm{r}$ (17); Nicolas, iii. I49-50.

${ }^{5}$ Rot. Parl. v. 407 ; iv. 343 ; Nicolas, iii. 213-2I iv. 59-66. 
was to wring a slight concession from the council under an ordinance made in I433, whereby they were to acquaint him with their nominations to the more important offices, and were even to consult him on conferring bishoprics. $^{1}$ It was not until the King assumed his powers, however, that the council's position was seriously challenged, and it is most unfortunate that the records of his policy are so meagre. If the whole truth were known, we might find that we had under-estimated Henry VI's energy; certainly the conflict was waged with great vigour by the King, who in 1437 , while still a boy, began to make his power felt. In appointing a 'privy council' he expressly reserved to himself the granting of offices, collations, and pardons, forbade them to conclude important business without his advice, and in cases of disagreement in the council, took it upon himself to form the decision. ${ }^{2}$ The warrants in the Record Office prove that Henry could substantiate his claim. Bills signed by the councillors are not so frequent from this date onwards, while on the other hand novel forms of warrant were forced upon the Privy Seal Office, which now had to be content with an endorsement testifying the King's pleasure that letters of privy seal be made, authenticated by the signature of a clerk, such as OSBERN, or more often, ADAM MOLEYNS; occasionally a witness is mentioned, but we hear much less of the council expediting business, while, deeply significant of the change is the presence of the Royal Sign Manual on scores of documents, which, it may be conjectured, were afterwards sealed with the signet as a cachet. The council's reverse was signalised in a fresh code of regulations, ${ }^{3}$ which most unfortunately cannot be dated with certainty, but the contents indicate that they were drawn up about the years 1440-3. The council recognised that the King, by sign-manual, or by the signature

\footnotetext{
${ }^{1}$ Rot. Parl. iv. $424(3,5)$.

I Ibid., v. 439 a.

${ }^{3}$ Nicolas, vi. 3r6-20.
} 
of the Chamberlain, could move the signet at his will, and that the privy seal could not be refused on the production of a signet bill; nevertheless, the council tried to hide its defeat behind a mass of details about witnessing the Royal Sign-Manual, which really did nothing to alter the situation, and even attempted to interfere with the Signet Office by ordaining that they should keep all their warrants, and possess copies of all the documents they passed. It is very improbable that these clauses had any effect. The King had clearly won at the signet, but as we shall see, the council was prepared to make a stand at the privy seal. The King might, and did, grant bills by the sign-manual on his own authority, and undoubtedly the secretary was in no position to refuse the signet to any bill that bore the King's mark; but when the signet-warrant comes to the Privy Seal Office, it is no longer in the King's but in the council's sphere of influence, and so the council, although they expressly admitted that the privy seal was normally commanded by the signet, still clung to a mere remnant of their former power, and bravely undertook to arrest a bill at the privy seal if it did not seem to them politic to allow it to travel further along the perilous path to the Chancery. The ordinance tells us how it could be done :-

'IтEm that the Kepere of the prive seal, what tyme he receyvethe lettres under the signet, shall, if it be thought to him that the matere conteyned in the same be of greet charge, have recours to the lords of the Counsaill and open to theim the matere, to thentente that if it be thought necessarie to theim, the King be advertised therof or it passe.'

It is hard to believe that the council meant this threat seriously, and it is much more probable that it was only an angry outburst by men who felt their position rudely shaken. Any doubt that still remained as to where the victory lay was soon removed by the King's triumphant 
edict of I444. He had already freed the signet, and forced the privy seal to obey its warrants, and only the great seal remained. The Chancery had kept out of the conflict by resolutely demanding (for ordinary purposes) a privy seal as warrant; even in certain matters of course, such as where the seal of the Treasurer usually procured the great seal directly, we sometimes find that the Chancellor had referred the warrants to the council, who expedited them in their own way by endorsement and thence through the Privy Seal Office; occasionally, it is true, we find both royal and conciliar immediate warrants on the Chancery files, but they are not numerous. The King now formally ratified all those warrants which the Chancellor had so far only accepted with reluctance, by assuring him that all grants made from the tenth year of the reign until then, by virtue of bills under the sign-manual, Signet of the Eagle, or Signet of Arms, as well as those signed by the Chamberlains and clerk of the council, were as legal as if the Chancellor had had a privy seal warrant, any statute, charge, restraint, act or commandment to the contrary notwithstanding. ${ }^{1}$ This declaration, dated November 7, 1444, was placed on the Patent Roll of the year, and may be regarded as closing the conflict, and the warrants to the privy seal which still remain show how quickly the council lost its grip of the administration. For the second half of the century, the crown, whether Lancastrian, Yorkist, or Tudor, jealously retained its own patronage for its own disposal, and the council had perforce to resign the spoils it had so long exploited, and seek fresh fields of endeavour.

Matters could hardly have resulted otherwise, for the council was rapidly undergoing changes which rendered it unfit to control such vital matters as the bestowal of large numbers of offices; not only were the men who composed it personally avaricious and violent, but the

${ }^{1}$ Cal. Pat. Hen. VI, iv. 312-3; Rymer, xi. 75. 
basic idea of the council was changing. Instead of a circle of men chosen by the King mainly on account of their probity and business skill, with just enough great names among them to give their meetings dignity, the council was now tending to consist mainly of magnates, with just enough professional civil servants to maintain the necessary routine. For a time they succeeded, but the scandals of their administration, and their own dissensions afforded the crown every opportunity of resuming its former powers, and we have seen how easily Henry VI entered upon his long-delayed inheritance, and how completely the council failed to justify or maintain its place at the centre of the administration.

By tracing these two lines of history it has thus been possible to illustrate the place taken by the continual council and the great council in Lancastrian politics; both clearly were influenced by the same two motives, namely, to enforce in a practical manner the dependence of the crown upon the magnates as a class, first in matters of general policy and finance, and secondly to secure an administrative position which would enable that class to exert a powerful influence in matters which had hitherto been the prerogative of the King, such as the distribution of rewards and offices. The first was effected by means of the great council, though necessarily only by occasional intervention; the second by the steady pressure of the continual council in the struggle for the seals, its own composition, moreover, throughout this period tending towards an increasing proportion of great lords. Henry VI's reign represents the zenith of this dual policy, and it was not until about $1436-7$ that Henry VI could begin a spirited contest for his patrimony. He was strong enough to deliver a decisive defeat to the continual council, and it never recovered in his reign, or subsequently, its former control over the vital points of seal-procedure. While this was in progress, however, 
the other issue of King versus Great Council was becoming more complicated by the successive degeneration of both protagonists; the great council first succumbed to the disintegration of the class it represented, and through the dissensions-even to the extent of armed conflictwithin its ranks, was soon unable to offer an opinion or to pursue a policy. If Henry VIII had been King in 1450 , commanding a position so firmly founded on prerogative and precedent, we might guess what would have happened, but the crown's opportunity was lost through Henry's own misfortunes; his personal affliction, indeed, may have been amply counter-balanced by the disorder in the baronial ranks, but his birth was fatal. The advancement of the Yorkist title cut the ground from under his feet; because he could not claim to be the undoubted representative of the kingship, so the ancient feud of crown against baronage was never fought out on a straight issue. Nevertheless, the crown won. Great councils and parliaments are both rare under the Yorkists and the first Tudor, and when they do meet, are uneventful; the continual council survived also, but the warrants for the privy seal have little to show of its work-instead there are sign-manuals everywhere. It is difficult to find it at all $;^{1}$ although many men are described as councillors, ${ }^{2}$ the council in its political aspect had practically ceased, and if we seek the lineal heir of the Lancastrian Council, we must look, not to the Privy Council of the next century, but to the Star Chamber.

This brings us to the consideration of the place of these institutions under the Yorkists, the last and perhaps the most difficult of all the questions raised in this paper. Great councils are rare and obscure ; as for the continual council, there is a great diminution of sources on all sides, and council documents are very scarce indeed. The archives preserved in the office of the privy seal

1 A. F. Pollard, Reign of Henry VII from Contemporary Sources, iii. 3I4.

2 Ibid. in Engl. Hist. Rev. xxxii. 455. 
are scanty and consist mainly of warrants under the sign-manual, but then the Patent Rolls are meagre also. There is, however, reason to believe that many instruments formerly under the privy seal, were now passed under the signet, which certainly executed a great amount of business, ${ }^{1}$ and some may have been expedited by the council, but this is very doubtful. That there was a council still is evident from what scraps of material yet survive, while from one or two lists that are extant, it seems to have been of considerable size-as many as fifty or more names may be found. ${ }^{2}$ For the whole of Henry VII's reign, and part of the next there was a Book of Entries which has vanished since the eighteenth century, and is now only known from the notes and extracts ${ }^{3}$ made by Madox and other antiquaries who were interested in the Court of Star Chamber, and regarded it as that court's Decree Book. There is reason to believe that the original was in Latin-for extracts in this language sometimes occur, accompanied by a translation, ${ }^{4}$ while more important still, we read such things as - The Maiour to be Comoned with by the Lords att the ffryars att afternoone; . . . a Bull to be translated into Englishe by my Lord of Lincolne'.5 This and a few similar phrases suggest that the original was more probably a memorandum book of the council, which contained many more such entries of a purely administrative nature, which were omitted by the transcribers as not germane to their subject. The council certainly met very frequently during the fifteenth century in the Star Chamber, and the mere occurrence of these words would be enough to catch the attention of these searchers.

The council was certainly undergoing a fundamental change in orientation. Its administrative activities seem

${ }^{1}$ The great bulk of MS. Harl. 433 is very suggestive.

2 Above, p. 185 , n. 2.

${ }^{3}$ MS. Add. 452I ; Hargrave MS. 2I6 and others.

4 MS. Add. $4521, f$ $106 \mathrm{~b}$, for example.

${ }^{5}$ Ibid. f ro5 b (x Hen. VII). 
considerably curtailed, and slowly but steadily it is becoming confined to 'billes betwix partie and partie,' and thus its old room, the Star Chamber, is taking a new significance. The details of the change are now forgotten, and few sources seem likely to elucidate the process, but certain it is that the King's Council is gradually becoming the Court of Star Chamber. What happened to its former mass of administrative work, is a mystery ; some of it was still done during the transition, but in the reign of Henry VIII we first meet the new body which was to take up the task. The PRIVy counciL, as it came to be called, had a very obscure genesis, and does not become prominent until after our period; but even then it is important to notice that it had to acknowledge the greater age and superior dignity of its elder brother, the King's Council, or as it was now styled, the Court of Star Chamber. When Burleigh made a speech in the Star Chamber he 'declared before all the Presence, that thesame Court was the Councell of State of this Realme, and the Clerke thereof the onely Clerke of the Councell of State, and Clerke of the Councell of England, and that there was noe other Clerke of the Queenes Councell of State, but onely the Clerke of this Courte, And that the others were Clerkes of the Privy Councell attendant upon her Majesties Royall person, and those other Clerkes were to attend at the Councell Table'. Then again, the Clerk of the Star Chamber 'was first Clerk of the Council in place, being so created by the Heralds at Queen Elizabeth [sic] passing through the City of London to St. Paul's in the year I 588 to give Almighty God thanks for the conquest of the Spanish King's navy '. Evidently the King's Council in the Star Chamber and its officials were well aware of their ancient ancestry stretching back through the Lancastrian age to even remoter times, and regarded the Privy Council and its Clerks as parvenus whose newer dignity was always to

${ }^{1}$ Scofield, Star Chamber, 62. 
be shown by their lower precedence. Another indication that the Star Chamber was the heir of the mediæval council is seen in the fact that just as the peers had claimed to be consiliarii nati, so, as late as Stuart times, they continued their claim to be present, not in the Privy Council, but in the Star Chamber. ${ }^{1}$ A still more remarkable phrase in the speech of Burleigh just cited is that in which he reproves a barrister who wished to follow the Common Law rules of pleading, by telling him that 'the same Courte is the great Councell of the King. And that at all tymes since there was a king of this Realme his greate Councelle might decide all offences complayned of before them' without strict pleading,-'yea, and many tymes without pleading at all'. ${ }^{2}$ This gradual change in the council's orientation undoubtedly took place in the half-century between the accessions of Edward IV and Henry VIII, but the details of the process are even more obscure than the rest of its history-save only, perhaps, the few years immediately following the Yorkist revolution. Notwithstanding the greater definition which is found in the middle of the century, at its close we are suddenly confronted by a phenomenon which can only be described as a reversion to type-that vague, elastic type we have already noticed, consisting of an indefinite class of men who had no organisation, no corporate existence, no bond of union whatever, save the shadowy nexus of 'counsel'. The younger Yorkist monarchy took 'counsel,' we may be sure, but whence, and how? The old Lancastrian institution seems to have become vaporised, so to speak, and after a short existence in this intangible state it gradually condensed again, still in the Star Chamber indeed, but amid new conditions which produced such profound differences, that we can only follow with the greatest difficulty the last change in the place of the council in our period, and then it is indeed

${ }^{1}$ Hudson, ap. Collectanea Furidica, ii. 25.

2 MS. Harg. 2r6, ff. r73 b-r 74 . 
a remarkable paradox; contemporaries all agreed that lack of firm governance was its besetting sin in Lancastrian days, but when it appears the second time in its ancient haunt, it is so purged of its former failing that the feeble council of Henry of Windsor is re-incarnated as the terrible tribunal of Henry Tudor.

The crowded century which separates the reign of Henry IV from that of Henry VIII has many sudden changes to record bearing emphatic witness to the importance of the council in its various aspects. The story of the long conflict concerning the seals exhibits for the first time the details of a determined attempt by the continual council to control the national administration, while the reasons for its failure have been found in the inability of the leading barons to forget their own interests in the exercise of the Royal patronage. The great council's history, moreover, runs a parallel course, while the intimate relations between it and the continual council show how closely both co-operated in the baronial policy of converting England into a virtual oligarchy. The council's position was clearly the political and constitutional aspect of the social conditions of the age, and from this circumstance it derived both its strength and its weakness; so strictly dependent, in fact, was the council's position upon the social structure of Lancastrian England, that it could not survive the passing of the old order, but vanished so completely as to leave its successor only a dim tradition of its ancient greatness. 